\title{
THICKNESS OF THE LIGAMENTUM FLAVUM OF THE SPINE AND ITS RELATIONSHIP WITH DISC DEGENERATION
}

\author{
ESPESSURA DO LIGAMENTO AMARELO DA COLUNA VERTEBRAL E SUA LIGAÇÃO \\ COM DEGENERAÇÃO DISCAL
}

\author{
ESPESOR DEL LIGAMENTO AMARILLO DE LA COLUMNA VERTEBRAL Y SU \\ RELACIÓN CON LA DEGENERACIÓN DEL DISCO
}

Thiago Mattar ${ }^{1}$, Alexandre Barros Costa ${ }^{1}$, Paulo Roberto Appolonio ${ }^{1}$, André Evaristo Marcondes Cesar ${ }^{1}$, Luciano Miller Reis Rodrigues ${ }^{1}$

\begin{abstract}
Objective: This study investigates whether the thickening of the ligamentum flavum (LF) is correlated with disc degeneration. Methods: This retrospective study was conducted with 98 patients with chronic low back pain treated in a spinal surgery service between January 2012 and January 2013. All patients underwent magnetic resonance imaging (MRI) and the images were evaluated by a spinal surgeon to measure the thickness of the LF and evaluate the degree of disc degeneration by the Pfirrmann grading system, according to the spinal levels (L3 -L4, L4-L5, L5-S1). An association was sought between LF hypertrophy and disc degeneration, age, sex and disc height. Results: The mean age of the patients was 53.6 years, and the majority were women (59.2\%). The thickness of the LF and disc height varied according to the spinal level, the greatest LF thickness being found between L4-L5, and the greatest disc height at L5-S1. Women had statistically thicker ligaments in L3/L4 than men. The degree of disc degeneration was inversely correlated with the height at all the levels evaluated, i.e., the greater the degree of degeneration, the lower the disc height. Conclusions: The thickening of LF is not related to disc height or degree of disc degeneration. Therefore, there is no deformation of the LF within the spinal canal secondary to disc degeneration.
\end{abstract}

Keywords: Spine; Ligamentum flavum; Intervertebral disc; Intervertebral disc degeneration.

\section{RESUMO}

Objetivo: Investigar se o espessamento do ligamento amarelo (LA) está correlacionado com a degeneração discal. Método: Este estudo retrospectivo foi realizado com 98 pacientes com dor lombar crônica, em acompanhamento ambulatorial em serviço especializado em cirurgia da coluna vertebral entre janeiro de 2012 e janeiro de 2013. Todos os pacientes foram submetidos a exames de ressonância magnética (RM) e as imagens foram avaliadas por um especialista em cirurgia da coluna vertebral para aferir e quantificar a espessura do LA e o grau de degeneração discal pelo método de Pfirrmann conforme os níveis da coluna (L3-L4, L4-L5, L5-S1). Analisaram-se a associação entre hipertrofia do LA e degeneração discal, idade e sexo dos pacientes e altura do disco. Resultados: A média de idade dos pacientes foi 53,6 anos, sendo a maioria do sexo feminino (59,2\%). A espessura do LA e a altura do disco variaram conforme o nível, com a maior espessura do LA entre L4-L5 e a maior altura discal em L5-S1. As mulheres apresentaram média estatisticamente maior de espessura do ligamento em L3/L4 que os homens. O grau de degeneração discal correlacionou-se inversamente com a altura em todos os níveis avaliados, ou seja, quanto maior o grau de degeneração, menor a altura do disco. Conclusões: O espessamento do LA não tem relação com a altura do disco ou com grau de degeneração discal. Subtende-se, portanto, que não há deformação do LA dentro do canal medular decorrente da degeneração discal.

Descritores: Coluna vertebral; Ligamento amarelo; Disco intervertebral; Degeneração do disco intervertebral.

\section{RESUMEN}

Objetivo: Investigar si el espesamiento del ligamento amarillo (LA) se correlaciona con la degeneración del disco. Método: Este estudio retrospectivo se llevó a cabo con 98 pacientes con dolor lumbar crónico en servicio de atención ambulatoria especializado en cirugía de columna, entre enero de 2012 y enero de 2013. Todos los pacientes fueron sometidos a una resonancia magnética (MRI) y las imágenes fueron evaluadas por un especialista en cirugía de columna para comparar y cuantificar el espesor del LA y el grado de degeneración del disco por el método de Pfirrmann, según los niveles de la columna vertebral (L3-L4, L4-L5, L5-S1). Se analizó la asociación entre la hipertrofia del ligamento amarillo y la degeneración del disco, la edad y el sexo de los pacientes y la altura del disco. Resultados: La edad media de los pacientes fue de 53,6 años y la mayoría eran mujeres (59,2\%). El espesor del LA y la altura del disco variaron según el nivel, con el mayor espesor del LA encontrado entre L4-L5 y la mayor altura del disco, en L5-S1. Las mujeres tuvieron estadísticamente mayor espesor medio del ligamento en L3/L4 que los hombres. El grado de degeneración del disco se correlacionó inversamente con la altura en todos los niveles evaluados, es decir, cuanto mayor sea el grado de degeneración del disco, menor será su altura. Conclusiones: El espesamiento del LA no tiene ninguna relación con la altura del disco o el grado de degeneración del disco. Esto implica, por lo tanto, que no hay deformación dentro del LA dentro del canal espinal debido a la degeneración del disco.

Descriptores: Columna vertebral; Ligamento amarillo; Disco intervertebral; Degeneración del disco intervertebral.

1. Faculdade de Medicina do ABC, Santo André, SP, Brazil. 


\section{INTRODUCTION}

The ligamentum flavum wraps around the medial aspect of the spinal articulations and is composed more of elastic than collagen fibers, hence its yellow color. Its elasticity diminishes with age, and there is a loss of the elastic fibers and a concomitant increase of collagen fibers. ${ }^{1}$ This ligament consists of a superficial and a deep component. The superficial component is inserted into the superior and posterosuperior edges of the caudal lamina. The deep component is inserted at a variable distance into the anterosuperior surface of the caudal lamina. Generally, the ligamentum flavum begins in the middle of the cephalic lamina and is inserted into the superior surface of the caudal lamina. ${ }^{2}$

Various authors have suggested that the ligamentum flavum plays an important role in vertebral disease, more specifically, in spinal stenosis., ${ }^{3,4}$ Thickening of the ligamentum flavum can reduce the diameter of the spinal canal, compressing the dural sac and the nerve roots and contributing to low back pain and sciatica, even in the absence of a protuberant fibrous ring, a herniated nucleus pulposus, or bone spurs. ${ }^{5,6}$

Although the ligamentum flavum thickens with age, other factors, including clinical diagnosis, pain, and function, do not seem to be related to the width of the ligamentum flavum. ${ }^{6}$ Several studies suggest that long-term wide segmental movement contributes to hypertrophy of the ligamentum flavum, and that this could be a key factor in stenosis and nerve compression. Altinkaya et al ${ }^{7}$ concluded that the thickening of the ligamentum flavum is correlated with disc degeneration, aging, body mass index, stenosis, and disc herniation, and that it is due to deformation within the vertebral canal, as a result of disc degeneration, rather than hypertrophy of the ligamentum flavum.

Although the narrowing of the disc space is an important factor in morbidity associated with lumbar spine disease, our investigation is focused on the hypothesis that degenerative changes in the disc lead to thickening of the ligamentum flavum. ${ }^{8}$ However, only one report of thickening of the ligamentum flavum due to hypertrophied or deformed tissue has been published, and that study questioned whether the thickening is related to disc degeneration in magnetic resonance imaging $(\mathrm{MRI}) .^{9}$

The objective of this study is to investigate the hypothesis that the thickness of the ligamentum flavum is correlated with the grade of disc degeneration according to the levels of the spine.

\section{METHODS}

This retrospective observational study was based on the case histories and imaging exams of all the patients with chronic low back pain submitted consecutively to MRI exams at the Outpatient Spinal Surgery Clinic of the Faculdade de Medicina do ABC between January 2102 and January 2013. Ninety-eight individuals were included in the study (56 of them women), with ages ranging from 15 to 87 years (average of 53.5 years with a standard deviation (SD) of 13.6 years).

Patients with at least three months of low back pain were included, while patients with transitional vertebrae, fractures, tumors or infections of the spine, prior surgeries, or deformities like scoliosis, kyphosis, or congenital malformations, such as spina bifida, were excluded.

All the patients were examined by MRI, with T1-sequence axial sections at three levels: L3-L4, L4-L5, and L5-S1. The same evaluator verified the degree of degeneration and thickening of the ligamentum flavum in all the cases.

The evaluation of disc degeneration was conducted according to the method of Pfirrmann et al, ${ }^{10}$ and included measuring the height of the anterior third of the disc.

The thickness of the ligamentum flavum was measured with an electronic ruler with a resolution of $0.1 \mathrm{~mm}$ by means of a line drawn transversally to the facet joint level (Figure 1) through the middle section of the ligamentum flavum. If the thickness was bilaterally asymmetrical, the measurement of the thickest part was used.

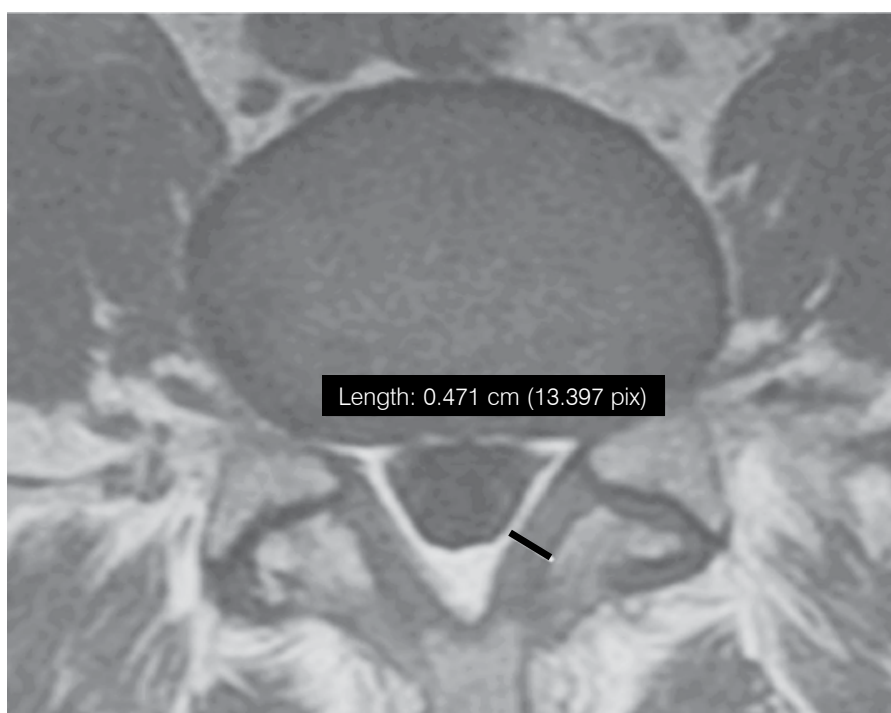

Figure 1. Measurement of the thickness of the ligamentum flavum in T1-weighted $\mathrm{MRI}$ scan at the level of the common facet joint.

\section{Statistical analysis}

In this study, the patient characteristics were described using the average and standard deviation for age and the absolute and relative frequencies for the sexes. The values of the thickness and height of the ligaments were described using summary measurements (average, standard deviation, median, minimum and maximum) and compared between the ligaments using analysis of variance (ANOVA) with repeated measurements. ${ }^{11}$ The Huynh-Feldt apud Neter et $a l^{11}$ correction was used to compare the height between the ligaments. The analyses were followed by Bonferroni apud Neter et a $/^{11}$ multiple comparisons to identify between which ligaments significant differences existed.

Pearson apud Kirkwood and Sterne ${ }^{12}$ correlations were calculated to determine the existence of correlations between height and thickness and age, and Spearman apud Kirkwood and Sterne ${ }^{12}$ correlations were calculated to determine the existence of correlations among the grades of disc degeneration and the heights and thicknesses of the ligaments.

The analyses were performed using the Statistical Package for Social Sciences (SPSS) software, version 17.0, and a level of significance of $5 \%(\alpha=0.05)$ was assumed for all tests.

\section{RESULTS}

The average age of the patients included in the study is 53.6 years (Table 1) and most of the patients are female (59.2\%).

Table 2 shows that the average thickness of the ligaments and average height of the discs vary significantly according to the levels $(p<0.001$ and $p=0.039$ respectively). Table 3 shows the pairwise comparisons: ligament at L4/L5 presents a statistically greater average thickness than ligaments at $L 3 / L 4$ and $L 5 / S 1(p<0.001)$, while the average thicknesses of ligaments at L3/L4 and L5/S1 are statistically equal $(p=0.621)$. However, in terms of the disc height,

Table 1. Description of patient characteristics.

\begin{tabular}{c|c|c}
\hline Variable & Frequency & $\%$ \\
\hline \multicolumn{3}{|c}{ Sex } \\
\hline Female & 58 & 59.2 \\
\hline Male & 40 & 40.8 \\
\hline \multicolumn{3}{|c}{ Age (years) } \\
\hline Average (SD) & $98.6(13.8)$ \\
\hline Total & 100 \\
\hline
\end{tabular}


even though a statistically significant average difference between the levels was verified ( $p=0.039$, as shown in Table 2 ), it was not possible to identify between which levels the difference in height really exists $(p>0.05)$.

Table 4 shows that female patients have a statistically greater average thickness of the ligament at $L 3 / L 4$ than male patients $(p=0.009)$. The association between age and the thickness of the ligament was not verified ( $p>0.05)$

Table 5 shows an inverse correlation between the grade of disc degeneration and disc height in all the levels evaluated, i.e. the greater the degeneration the lower the height of the disc $(p<0.05)$.

Table 2. Description of thickness and height of each ligament and the results of comparison between the ligaments: analysis of variance with repeated measures (ANOVA).

\begin{tabular}{c|c|c|c|c|c|c|c|c}
\hline Variável & Level & Average & SD & Median & Minimum & Maximum & $\mathbf{N}$ & $\mathbf{p}$ \\
\hline \multirow{4}{*}{ Thickness } & $\mathrm{L} 3 / \mathrm{L} 4$ & 0,26 & 0,08 & 0,27 & 0,10 & 0,50 & 98 & \multirow{3}{*}{} \\
\cline { 2 - 9 } & $\mathrm{L} 4 / \mathrm{L} 5$ & 0,35 & 0,10 & 0,34 & 0,17 & 0,58 & 98 & $<0,001$ \\
\cline { 2 - 8 } & $\mathrm{L} 5 / \mathrm{S} 1$ & 0,27 & 0,08 & 0,27 & 0,14 & 0,54 & 98 & \\
\hline \multirow{4}{*}{ Height } & $\mathrm{L} 3 / \mathrm{L} 4$ & 0,93 & 1,27 & 0,79 & 0,34 & 13,20 & 98 & \multirow{2}{*}{} \\
\cline { 2 - 8 } & $\mathrm{L} 4 / \mathrm{L} 5$ & 1,15 & 2,38 & 0,91 & 0,24 & 24,30 & 98 & $0,039^{*}$ \\
\cline { 2 - 7 } & $\mathrm{L} 5 / \mathrm{S} 1$ & 1,24 & 2,70 & 0,97 & 0,19 & 27,50 & 98 & \\
\hline
\end{tabular}

with Huynh-Feldt correction.

Table 3. Results of the Bonferroni multiple comparisons between the thicknesses and heights between the ligaments according to level.

\begin{tabular}{c|c|c|c|c|c|c}
\hline \multirow{2}{*}{ Variable } & Comparison & $\begin{array}{c}\text { Average } \\
\text { difference }\end{array}$ & $\begin{array}{c}\text { Standard } \\
\text { error }\end{array}$ & $\mathbf{p}$ & \multicolumn{2}{|c}{ Cl (95\%) } \\
\cline { 5 - 7 } & Inferior & Superior \\
\hline \multirow{4}{*}{ Thickness } & L3/L4 - L4/L5 & -0.08 & 0.010 & $<0.001$ & -0.11 & -0.06 \\
\cline { 2 - 7 } & L3/L4 - L5/S1 & -0.01 & 0.009 & 0.621 & -0.03 & 0.01 \\
\cline { 2 - 7 } & L4/L5 - L5/S1 & 0.07 & 0.011 & $<0.001$ & 0.05 & 0.10 \\
\hline \multirow{3}{*}{ Height } & L3/L4 - L4/L5 & -0.23 & 0.114 & 0.155 & -0.50 & 0.05 \\
\cline { 2 - 7 } & L3/L4 - L5/S1 & -0.31 & 0.147 & 0.108 & -0.67 & 0.05 \\
\cline { 2 - 7 } & L4/L5 - L5/S1 & -0.09 & 0.044 & 0.139 & -0.19 & 0.02 \\
\hline
\end{tabular}

$\mathrm{Cl}=$ confidence interval.

\section{DISCUSSION}

We know that the ligamentum flavum is a connective tissue that runs from the second cervical vertebra to the first sacral vertebra. ${ }^{13}$ Its function affects the intrinsic stability of the vertebral spine, controls intervertebral movement, and maintains a smooth surface for the dural sac. ${ }^{5}$

The pathogenesis of thickening of the ligamentum flavum is not clear. There is still controversy as to whether the thickening is due to hypertrophy of the tissue or deformation. Some studies state that the narrowing of the canal is the result of hypertrophy of the ligament, while others argue that deformities of the ligamentum flavum inside the spinal canal compress the nerve tissues. ${ }^{1,6,9}$ Additionally, the terms "thickening" and "hypertrophy" are used interchangeably in the literature, although they are not necessarily the same thing. ${ }^{13}$

Table 5. Result of the correlations of interest for each ligament.

\begin{tabular}{c|c|c|c|c}
\hline Level & Variables & Correlation & $\mathbf{N}$ & $\mathbf{p}$ \\
\hline \multirow{4}{*}{ L3/L4 } & Age versus height & 0.037 & 98 & 0.717 \\
\cline { 2 - 5 } & Age versus thickness & 0.170 & 98 & 0.093 \\
\cline { 2 - 5 } & Height versus thickness & -0.077 & 98 & 0.449 \\
\cline { 2 - 5 } & Pifirrmann versus height* & -0.305 & 98 & 0.002 \\
\cline { 2 - 5 } & Pifirrmann versus thickness* & 0.061 & 98 & 0.553 \\
\hline \multirow{5}{*}{ L4/L5 } & Age versus height & 0.034 & 98 & 0.739 \\
\cline { 2 - 5 } & Age versus thickness & 0.124 & 98 & 0.223 \\
\cline { 2 - 5 } & Height versus thickness & 0.015 & 98 & 0.881 \\
\cline { 2 - 5 } & Pifirrmann versus height* & -0.535 & 98 & $<0.001$ \\
\cline { 2 - 5 } & Pifirrmann versus thickness & 0.019 & 98 & 0.852 \\
\hline \multirow{4}{*}{ L5/S1 } & Age versus height & 0.034 & 98 & 0.742 \\
\cline { 2 - 5 } & Age versus thickness & 0.033 & 98 & 0.747 \\
\cline { 2 - 5 } & Height versus thickness & 0.132 & 98 & 0.197 \\
\cline { 2 - 5 } & Pifirrmann versus height* & -0.201 & 98 & 0.047 \\
\cline { 2 - 5 } & Pifirrmann versus thickness* & -0.048 & 98 & 0.637 \\
\hline
\end{tabular}

Result of the Pearson correlation; * Result of the Spearman correlation.

Table 4. Description of the disc heights and ligament thicknesses according to sex, and results of comparisons between the sexes (Student's t-test).

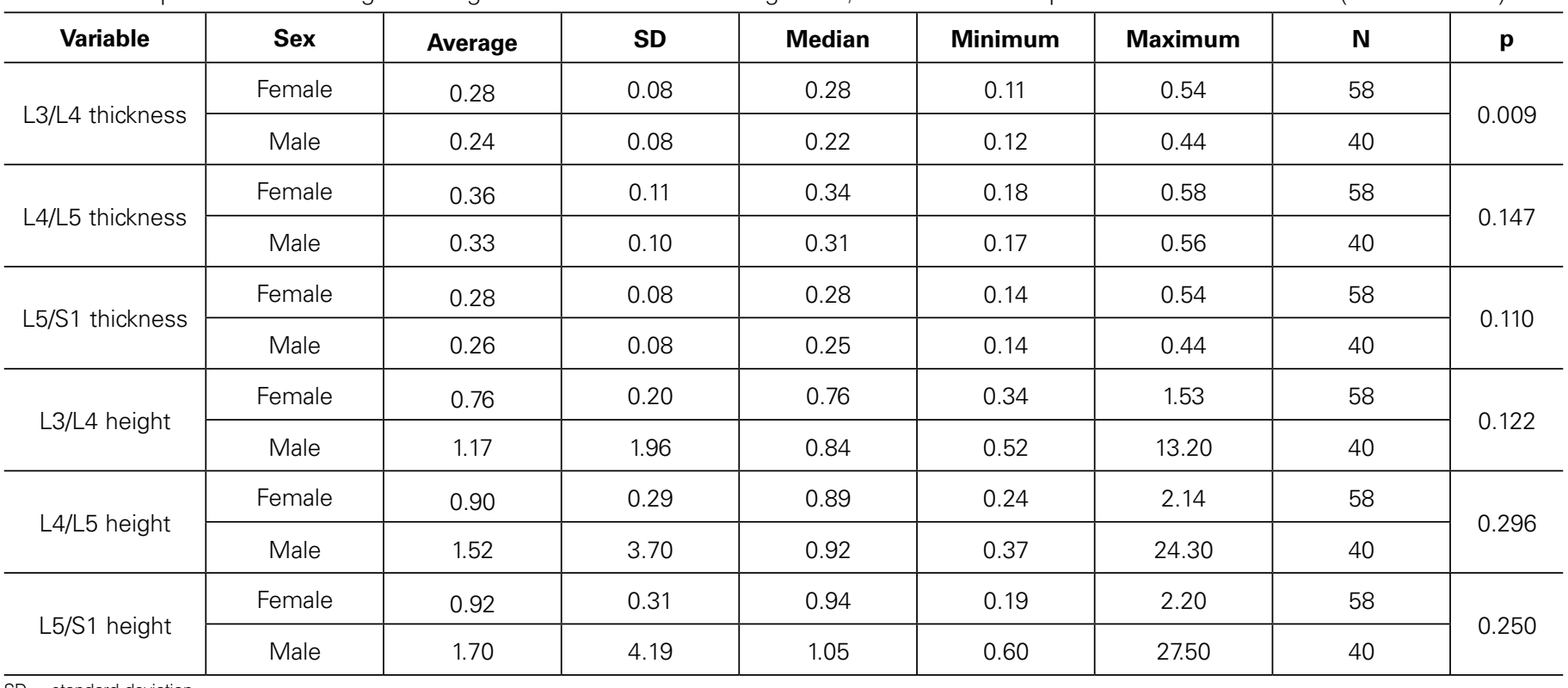


Studies of the pathophysiology of the ligamentum flavum emphasized the factors that affect its thickness, mainly in segmental instability. ${ }^{3,4,6-9,14,15}$ However, only Sakamaki et a/ ${ }^{9}$ described the thickening of the ligamentum flavum as being caused by hypertrophied or deformed tissue, and they questioned whether it was related to disc degeneration in the MRI exams.

To assess this theory, the relationship between the thickness of the ligamentum flavum, the degeneration of the intervertebral disc, and disc height at L3-L4, L4-L5, and L5-S1 was examined. We confirmed that the thickness of the ligamentum flavum at levels L3-L4, L4-L5, and L5-S1 was not significantly greater in patients with grade IV and $V$ degeneration than in those with grade I to III degeneration. These results suggest that thickening of the ligamentum flavum is not due to the deformation of this ligament inside the vertebral canal as a result of disc degeneration.

As in Sakamaki et $a{ }^{9}$, our study did not find a correlation between the thickness of the ligamentum flavum and disc degeneration. However, unlike previous studies, ${ }^{9,13,16}$ we did not find any association between thickness and age, probably due to the size of our sample. An association between thickness and the female sex was only apparent at level L3-L4.

A limitation of our study is the fact that we measured the thickness of the ligamentum flavum only at the facet joint section and not in the other locations where it was present, failing to take into account the complex geometric morphology of the vertebral canal. In addition, we did not have data or MRI exams of individuals without low back pain or leg pain that could have been used as a control group for comparison, which should be implemented in a future study. Furthermore, parameters for the normal thickness of the ligamentum flavum of the vertebral spine do not exist in the literature and, when these are recorded, histopathological analysis should be included.

\section{CONCLUSION}

The results of this study suggest that the thickening of the ligamentum flavum has no relationship to disc height and grade of disc degeneration. Therefore, it is understood that there was no deformation or hypertrophy of the ligamentum flavum inside the spinal canal secondary to disc degeneration.

All authors declare no potential conflict of interest concerning this article.

\section{REFERENCES}

1. Kosaka H, Sairyo K, Biyani A, Leaman D, Yeasting R, Higashino K, et al. Pathomechanism of loss of elasticity and hypertrophy of lumbar ligamentum flavum in elderly patients with lumbar spinal canal stenosis. Spine (Phila Pa 1976). 2007;32(25):2805-11.

2. Olszewski AD, Yaszemski MJ, White AA 3rd. The anatomy of the human lumbar ligamentum flavum. New observations and their surgical importance. Spine (Phila Pa 1976). 1996:21(20):2307-12.

3. Yoshida M, Shima K, Taniguchi Y, Tamaki T, Tanaka T. Hypertrophied ligamentum flavum in lumbar spinal canal stenosis. Pathogenesis and morphologic and immunohistochemical observation. Spine (Phila Pa 1976). 1992:17(11):1353-60.

4. Grenier N, Kressel HY, Schiebler ML, Grossman RI, Dalinka MK. Normal and degenerative posterior spinal structures: MR imaging. Radiology. 1987;165(2):517-25.

5. Safak AA, Is M, Sevinc O, Barut C, Eryoruk N, Erdogmus B, et al. The thickness of the ligamentum flavum in relation to age and gender. Clin Anat. 2010;23(1):79-83.

6. Park JB, Chang H, Lee JK. Quantitative analysis of transforming growth factor-beta 1 in ligamentum flavum of lumbar spinal stenosis and disc herniation. Spine (Phila Pa 1976). 2001;26(21):E492-5

7. Altinkaya N, Yildirim T, Demir S, Alkan O, Sarica FB. Factors associated with the thickness of the ligamentum flavum: is ligamentum flavum thickening due to hypertrophy or buckling? Spine (Phila Pa 1976). 2011:36(16):E1093-7.

8. Chokshi FH, Quencer RM, Smoker WR. The "thickened" ligamentum flavum: is it buckling or enlargement? AJNR Am J Neuroradiol. 2010;31(10):1813-6.

9. Sakamaki T, Sairyo K, Sakai T, Tamura T, Okada Y, Mikami H. Measurements of ligamentum flavum thickening at lumbar spine using MRI. Arch Orthop Trauma Surg. 2009:129(10):1415-9.

10. Pfirrmann CW, Metzdorf A, Zanetti M, Hodler J, Boos N. Magnetic resonance classification of lumbar intervertebral disc degeneration. Spine (Phila Pa 1976). 2001:26(17):1873-8.

11. Neter J, Kutner $\mathrm{MH}$, Nachtsheim CJ, Wasserman W. Applied linear statistical models. 4th ed. Chicago, IL: Irwin; 1996

12. Kirkwood BR, Sterne JAC. Essential medical statistics. 2nd ed. Blackwell Science: Massachusetts: 2006.

13. Abbas J, Hamoud K, Masharawi YM, May H, Hay O, Medlej B, et al. Ligamentum flavum thickness in normal and stenotic lumbar spines. Spine (Phila Pa 1976). 2010:35(12):1225-30.

14. Hur JW, Hur JK, Kwon TH, Park YK, Chung HS, Kim JH. Radiological significance of ligamentum flavum hypertrophy in the occurrence of redundant nerve roots of central lumbar spinal stenosis. J Korean Neurosurg Soc. 2012;52(3): 215-20.

15. Park JB, Lee JK, Park SJ, Riew KD. Hypertrophy of ligamentum flavum in lumbar spinal stenosis associated with increased proteinase inhibitor concentration. J Bone Joint Surg Am. 2005;87(12):2750-7.

16. Sairyo K, Biyani A, Goel V, Leaman D, Booth R Jr, Thomas J, et al. Pathomechanism of ligamentum flavum hypertrophy: a multidisciplinary investigation based on clinical, biomechanical, histologic, and biologic assessments. Spine (Phila Pa 1976). 2005;30(23):2649-56. 